\title{
Will the Real Transitology Please Stand Up?
}

DOI:

10.1163/22115897-90000059

\section{Document Version}

Accepted author manuscript

Link to publication record in Manchester Research Explorer

\section{Citation for published version (APA):}

Haskell, J. (2016). Will the Real Transitology Please Stand Up? Baltic Yearbook of International Law Online, 15(1), 62 - 76. https://doi.org/10.1163/22115897-90000059

\section{Published in:}

Baltic Yearbook of International Law Online

\section{Citing this paper}

Please note that where the full-text provided on Manchester Research Explorer is the Author Accepted Manuscript or Proof version this may differ from the final Published version. If citing, it is advised that you check and use the publisher's definitive version.

\section{General rights}

Copyright and moral rights for the publications made accessible in the Research Explorer are retained by the authors and/or other copyright owners and it is a condition of accessing publications that users recognise and abide by the legal requirements associated with these rights.

\section{Takedown policy}

If you believe that this document breaches copyright please refer to the University of Manchester's Takedown Procedures [http://man.ac.uk/04Y6Bo] or contact uml.scholarlycommunications@manchester.ac.uk providing relevant details, so we can investigate your claim.

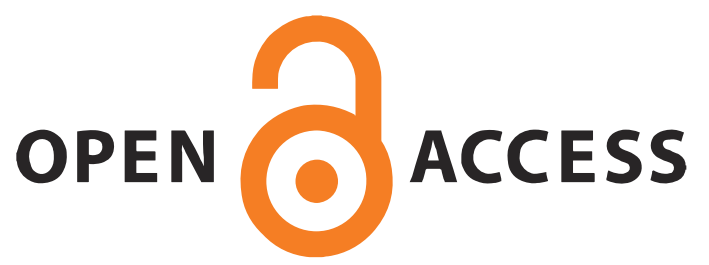


TO BE PUBLISHED IN BALTIC YEARBOOK OF INTERNATIONAL LAW, VOL. 15, 2015

HTTP://WWW.BRILL.COM/PUBLICATIONS/BALTIC-YEARBOOK-INTERNATIONAL-LAW

Will the Real Transitology Please Stand Up?

JOHN D. HASKELL*

TABLE OF CONTENTS

I. A CURIOUS EXCEPTIONALISM ................................. 1

II. IMAGINED TRAJECTORIES ..................................... 5

III. BLIND SPOTS ................................................

9

IV. The Great Game or a Tournament of Shadows ................. 13

\section{A CURIOUS EXCEPTIONALISM}

Perhaps no country more than Russia occupies the role of 'the Other' in Western-oriented governance. No other world political actor is so comprehensively identified with a set of negative connotations, from Stalin's Gulag to security state totalitarianism. Moreover, these images seem all the more real in today's political milieu: Russia's stance against the LGBT 
community, ${ }^{1}$ its imprisonment of Pussy Riot, ${ }^{2}$ its recent incursion into Crimea and Ukraine, ${ }^{3}$ and the mysterious death of Alexander Litvinenko and other journalists. ${ }^{4}$ If there is a stable world order, then Russia is the perennial exception. Perhaps more importantly, unlike other proposed anomalies (e.g., Muslim countries), Russia's deviations are not rooted in Western prejudice but rather stand for a very real threat to a global rule of law.

Of course, to speak of an 'Other' engenders an immediate suspicion that is now commonplace among Western academic and policy-making circles. Since one's identity is never purely rooted in a hermeneutically sealed authenticity but always situated in relation to others, the juxtaposition of an 'Other' is always an indirect acknowledgement of the outsider's constitutive influence in one's own constitution, that the strangeness of the 'Other' is at least partly a fantasy that is projected upon them to create a sense of oneself as it is a reality that confronts an already given personality. ${ }^{5}$ Meaning always requires an identification of what we are not, in other words, and that negation is always something intimate and partly unreal. If the Soviet Union is truly the counterpart to the 'West', this must be a symbiotic relationship: each

*Dr. John D. Haskell; Assistant Professor, Mississippi College School of Law (MC Law); Honorary Research Fellow, Durham Law School; Co-Director, International and Comparative Law Center. This paper was written with the generous support of the Institute for Global Law and Policy (IGLP, Harvard Law School) and MC Law, and I am grateful as always to David Kennedy, as well as Dean Jim Rosenblatt and Dean Wendy Scott. In particular, the discussion here benefited extensively from reading their scholarship and many conversations with Boris Mamlyuk, Scott Newton and Akbar Rasulov. An early version of this paper was presented at a conference organized by Lauri Mälksoo earlier this year, and I appreciate his invitation, encouragement, and patience, without which this paper would not have come together as it did.

${ }^{1}$ See Human Rights Watch, Russia: Anti-LGBT Law a Tool for Discrimination, 30 June 2014, <www.hrw.org/news/ 2014/06/29/russia-anti-lgbt-law-tool-discrimination>, visited on 30 August 2014.

2 See P. Catapano, 'Pussy Riot, Putin and the Law of the Cossack', New York Times Editor's Blog, 20 February 2014, $<$ takingnote.blogs.nytimes.com/2014/02/20/pussy-riot-putin-and-the-law-of-the-cossack/? _php $=$ true\&_type $=$ blogs\&_r $=0>$, visited on 30 August 2014.

3 See 'War, Not Peace: The evidence of Russian incursions into eastern Ukraine becomes ever clearer', The Economist, 30 August 2014, <www.economist.com/news/europe/21614190-evidence-russian-incursions-easternukraine-becomes-ever-clearer-war-not-peace>, visited on 30 August 2014; see also Anna Dolidze, 'Ukraine InstaSymposium: Potential Non-recognition of Crimea', Opinio Juris, 17 March 2014, <opiniojuris.org/2014/03/17/ ukraine-insta-symposium-potential-non-recognition-crimea/>, visited on 30 August 2014.

${ }^{4}$ See M. Jordan and P. Finn, "Radioactive Poison Killed Ex-Spy', Washington Post Foreign Service, 25 November 2006, <www.washingtonpost.com/wp-dyn/content/article/2006/11/24/AR2006112400410.html>, visited on 30 August 2014.

${ }^{5}$ This constitutive relationship between the 'self' and the 'other' is a prevalent theme in liberal political philosophy and international law. See e.g., E. Said, Orientalism (1979); see also A. Anghie, Imperialism, Sovereignty and the Making of International Law (2005). 
party reacting to the other, misrepresenting their opponent, developing their domestic and foreign policy to account for the image (and realities, understood or not) represented in their antagonist. Is it possible to dismiss that the political and legal debates throughout the Cold War (or afterward) portray a certain degree of rhetoric, of fantasy, of projection? Some will try to make such an argument otherwise, but not very convincingly.

If Russia (and the legacy of the Soviet Union more generally) is depicted in terms of its otherness, it is also perceived as an inherently unstable phenomenon in global governance. Its past, present and future is conceived to be perpetually moving - not simply in respect to how we conceive of all cultures as always negotiating transformation and continuity, but something more fundamental, as the subject par excellence of transition, of development from a particular origin and toward an identified aspiration. ${ }^{6}$ This transitional narrative encompasses the Western conception of Eastern Europe since the rise of Western European industrial capitalism in the $19^{\text {th }}$ century to the contemporary moment, and might generally be framed according to three general periods: first, in the pre-WWI era (e.g., uncivilized but a growing force to be reckoned with in foreign affairs); second, in the long 20th century experience of the Cold War (e.g., by the Soviet Union itself, as the 'developmental' state on steroids); and finally, in the wake of the disillusion of the former Soviet Union in the 1990s (e.g., its dismantlement literally described as 'transitology'). What is this country, this place, this institutionalized set of ideas, of energy, of organizational apparatuses that could be both the ultimate threat, the absolute representation of 'otherness', and yet also so inconsistent and transitory?

This question is complicated by a third observation that the liberal capitalist system, from its modes of production to its cosmopolitan ideals, seem to be running out of steam (or at least appearing more fragile) whether that is due to a lack of persuasion or more likely, as a result of a mixture of internal contradictions and external resource limitations. Resource wars, environmental calamities, irreparable industrial catastrophes, unmanageable domestic and international inequality appear not simply as challenges, but inescapable phenomena that evade

\footnotetext{
6 See S. Newton, Law and the Making of the Soviet world: the Red Demiurge (to be published 28 November 2014) (manuscript currently on file with author). Because the manuscript will not be published until later this year, I have refrained from incorporating Newton's study into this text - however, Newton's encyclopedic and insightful analysis (if not the most definitive take on the former Soviet Union's legal legacy) cannot but help inform my own understanding of the topic, and I am deeply indebted to his conversations and work.
} 
any integrated policy solutions. ${ }^{7}$ Of course, it may be that these global dilemmas would have occurred regardless of shifts in geopolitical thought over the last thirty years, but it is nevertheless a disturbing coincidence that there is an almost exact correspondence between the dissolution of the former Soviet Union and the subsequent 'crisis of capitalism'. Is there a connection, and if so, what?

Furthermore, in the wake of the global financial (political) crisis of 2008 and the resurgence of left and right wing ideologies throughout much of the international community, these questions seem even more pressing. Was the Soviet Union, beyond the martial struggle between 'Stalin and Hitler' (and at such incalculable human costs) an actual barrier to fascism? Can the Marxist legacy, for all its reliance on industrial led growth, point to an alternative global re-ordering for future policymaking? For that matter, to the extent that these questions might be conceivably answered in the affirmative, how would one dismiss the direct economic and political horrors associated with the Soviet Union over the course of the $20^{\text {th }}$ century? And, to push this question further, how exactly did the former Soviet Union, or any other political order claiming a Marxist-orientation, actually organize over this period? It is one thing to cite scholars or empirical data, but another thing to understand the actual operation and rationales behind institutional apparatuses. In the case of the Soviet Union, for example, there was a strong disconnect between legal theory and administrative practice, especially in the most revolutionary periods of the country. ${ }^{8}$ How many partisans can actually speak sufficiently on these terms? And yet, we seem to all hold such strong convictions about the legacy of the Soviet Union, and in contemporary terms, Russians.

\footnotetext{
${ }^{7}$ This theme seems endemic to contemporary popular and scholarly media. See e.g., H. Kissinger, 'The concept that has underpinned the modern geopolitical era is in crisis', The Wall Street Journal, 29 August 2014, <online.wsj.com/ articles/henry-kissinger-on-the-assembly-of-a-new-world-order-1409328075>, visited on 30 August 2014.

8 See B. Mamlyuk, Russia's Two Twenty-Years' Crises (1919-1939 \& 1989-2009): Economic Constraints on the Development of International Law pp. 11-13 (PhD Thesis, on file with author); see also Newton, supra note 6, pp. 8-9. Mamlyuk's thesis will be published in 2015 and offers a number of valuable insights into the archival history of $20^{\text {th }}$ century Soviet international law.
} 
Almost 25 years on from the dismemberment of the Soviet Union, these questions are only beginning to be raised by Western based scholars. ${ }^{9}$ This itself seems surprising: if the former Soviet Union was such a central dynamic in $20^{\text {th }}$ century history, why are we so unfamiliar with its actual workings? It cannot merely be an issue of suppression since looking back throughout the last century, analysis largely fell along strikingly partisan, or embarrassingly amateurish, fault lines - all of which has not really been cured since the end of the Cold War. Equally, the question might be raised, why now do scholars suddenly turn again to Russia and Soviet history, suddenly offering much more nuanced analyses of $20^{\text {th }}$ century Cold War dynamics of what exactly was going on? This paper does not attempt to respond directly to these questions, but rather (albeit concisely) backs up why such questions are important by returning to the legacy of Russia (and the Soviet Union) through these dueling imaginations of 'otherness' and 'transition'.

As a final word before moving forward, I want to foreground my own anxieties in writing this paper. The paper is organized to address the oscillations of Russia (and the Soviet Union) in terms of its 'Otherness' to the West. Each section is rather cursory and is only meant as a preliminary study into the given period, more a set of intuitions and reflections than a comprehensive or in-depth analysis of how this knowledge was and continues to be produced. ${ }^{10}$ On the one hand, there is a certain routinized boredom in how international lawyers and diplomats discuss current affairs in relation to Russia, whether speaking from Western-oriented or Eastern European perspectives. The moment we identify the speaker's institutional home, or hear the manner their argument is framed, the outcome is often predictable and old. On the other hand, there is something equally frustrating when listening to self-proclaimed Western Marxists talk about 'capitalism' (and by extension, the former Soviet Union). Each sound rehearsed (e.g., policy makers and diplomats) or uninformed (e.g., Left or Right members of the public or

\footnotetext{
${ }^{9}$ Mamlyuk and Newton are two prominent examples, though their work is part of a potentially growing interest in Soviet and post-Soviet law. See e.g., B. Bowring, 'Russia and Human Rights: Incompatible Opposites?', 1:2 Gottingen Journal of International Law (2009) pp. 33-54; see also T. Långström, Transformations in Russia and International Law (2003); C. Miéville, Between Equal Rights: A Marxist Theory of International Law (2005) pp. $75-152$.

10 There is a wealth of secondary literature for those interested in analyzing Soviet law within disciplinary, historical and institutional contexts. To conform to the publication requirements of this text, I have kept all footnotes to a minimum, often only noting some key authors within these debates.
} 
academia). In the face of potentially escalating conflict throughout Eastern Europe and Central Asia, my goal is only to briefly highlight a few blind spots that I see commonly arise through three phases of transition and otherness.

\section{IMAGINED TRAJECTORIES}

For the last 150 years, Western international legal scholars and politicians oscillated between seeing Russia as a central threat to their own interests and a backward country in need of tutelage. These feelings were not mutually exclusive, and in fact played off one another, but led to curious recommendations. The general sentiment, which seems strikingly familiar today, is that Russia was 'behind the times' and yet also was a dominant brute force that required if not accommodation, at the very least, extreme political calculation. In this section, I briefly evaluate depictions of this feeling towards Russia through three moments: the $19^{\text {th }}$ century colonial experience, the $20^{\text {th }}$ century phenomena of the 'cold war', and the contemporary post-Soviet period. Of course, Russia factored into the foreign affairs of political administrations in what would become Western Europe much earlier, but it was only in the $19^{\text {th }}$ century that a configuration emerged across a variety of terrains that we might call 'modern', including phenomena such as centralized state bureaucracies legitimized on the basis of 'national' populations, international law as an institutionalized discipline within the universities that provided the conceptual language for trans-state governance, and technological advances that began to bring the world into much more intimate, even daily, interaction. ${ }^{11}$

As with each moment, there was no uniform depiction of Russia in the $19^{\text {th }}$ century. Well documented, the Holy Alliance was perceived by many European diplomats as an anachronistic attempt of royal families to suppress the emerging bourgeois-oriented state systems legitimated on the basis of the 'nation' and a formalized conception of the rule of law. ${ }^{12}$ In an albeit unstable

\footnotetext{
${ }^{11}$ Dating the international legal profession to the mid-to-late $19^{\text {th }}$ century is becoming an important premise within the discipline, its methodological and theoretical implications that are only beginning to be explored. See e.g., M. Koskenniemi, The Gentle Civilizer of Nations: The Rise and Fall of International Law 1870-1960 (2001).

12 "Russia may be said . . . to furnish us with the extreme opposite to self government . . the symbol of the most absolute government ... a most automaton like government played by the czar ... There is no other way to escape from the appalling dilemma than to unite the people and government into one living institution." F. Lieber, On Civil Liberty and Self-Government I (1853) pp. 325-326.
} 
political terrain, Tsarist efforts were out-of-touch strategies to ensure traditional modes of order in contrast to the growing feeling that 'civilization' necessitated constant and dynamic progress. The goal, for many diplomats and international lawyers, was to harness the self-conscious 'nation' to foster comprehensive development in all fields of domestic and foreign affairs (e.g., economic, military, scientific), and within this story, Russia had little to offer the march of civilization. ${ }^{13}$ Though Russia did implement periodic legal and economic reforms in the $18^{\text {th }}$ and $19^{\text {th }}$ centuries, the economic base of the country remained primarily agrarian and the sociopolitical structure remained built around dynastic rule at the top and village communities within the population. ${ }^{14}$

At the same time, if Russia was considered outside modernity, in terms reminiscent of the colonial mindset towards non-European populations, it was considered a military phenomenon that needed careful handling: sometimes enlisting as an ally (e.g., against Napoleon), other times encountered on the battle field to halt territorial expansion that might disrupt colonial holdings in India and elsewhere (e.g., Crimean War, the Eastern Question). ${ }^{15}$ Moreover, the treatment of its Jewish minority population and the prevalence of 'pan-Slavic' ideology among Russian intellectuals and the population at large provided easy targets for ratcheting up the rhetoric of foreign threat to the prosperity and stability of the Western European system. ${ }^{16} \mathrm{~A}$ set of dichotomies operated to frame engagement and understanding of Russia: agriculture versus industry, peasants versus professionals, dynastic pedigree versus democratic (or republican) society, violence versus the rule of law, and so on.

By the time of the Bolshevik overthrow of the Tsar, the regime was already collapsing under the weight of crushing national debt, a lack of technological innovation (e.g., the railroad),

\footnotetext{
13 "All Russia is nothing but a vitiated nobility and a groaning serfdom, which ... have produced nothing but coarse increase in territory. What thought, what institution, what science, has Russia contributed to the stock of civilization?" F. Lieber, 'Letter to William C. Preston, July 28, 1855', in T.S. Perry (ed.), The Life and Letters of Francis Lieber (1882) p. 283.

14 For a brief discussion of Russian legal reforms in the $18^{\text {th }}$ and $19^{\text {th }}$ centuries, see B. Bowring, Law, Rights and Ideology in Russia: Landmarks in the Destiny of a Great Power (2013) pp. 21-47.

${ }^{15}$ See E. Hobsbawm, The Age of Capital: 1848-1875 (1996) pp. 75-77.

16 Ibid., pp. 162-182; see also J.L. Gaddis, The Long Peace: Inquiries into the History of the Cold War (1989) p. 8; W. LaFeber, America, Russia, and the Cold War, 19452006 (2008) p. 3.
} 
territorial over-expansion, and most importantly, exhaustion with the human cost of World War I. ${ }^{17}$ Though Russia had sided with the victors, countries such as Britain and the United States had tense relations with Russia going into the war and in the early post-war years helped finance 'White' militaries to combat Bolshevik control in the hope to instill more friendly allies that might be influenced to respect the 'rimlands' of Europe and Asia and temper the ideological rhetoric that might otherwise give new energy to left wing orientations already prevalent throughout Western societies. ${ }^{18}$ For the next fifty years or so, the United States and Russia would become the common reference points in geopolitical contest with both camps engaged in a selfconscious race to demonstrate their superiority across all fields of governance and social life. Again, similar tropes emerged among Western scholars. If we had a democratic system governed by the rule of law, Russia was a lawless regime ruled by a tyrant. If we accommodated religion and individual freedom, Russia stood for a militant atheism that demanded complete subservience of the individual to the prerogitives of the party. ${ }^{19}$ Both sides promoted national self-determination movements throughout the former colonized world and accused their counterpart of hegemonic ambition. Each claimed time to be on their side, the United States arguing Russia to be an aberration of progress and Russia claiming the United States to be in the last stages of imperial dominance before slipping out of the future. ${ }^{20}$ These claims were, of course, both real and imagined. For instance, though Russia would eventually collapse in the last decades of the $20^{\text {th }}$ century, its rapid industrialization and capacity to maintain full employment while most Western democracies slipped into economic malaise in the 1930s made an impressive case that Russia was a real contender for global dominance. ${ }^{21}$ Likewise, though the Soviet Union would condemn the United States foreign development aid as a form of informal imperialism, its

\footnotetext{
17 See E. Hobsbawm, The Age of Extremes: A History of the World, 1914-1991 (1996) p. 60.

${ }^{18}$ Ibid., p. 64; see Gaddis, supra note 16, p. 22.

${ }^{19}$ For a Cold War period example of this line of thinking, see e.g., J.E. Hoover, Masters of Deceit (1958); see also S. Belletto and D. Grausam (eds.), American Literature and Culture in an Age of Cold War: A Critical Reassessment (2012).

${ }^{20}$ See J.D. Haskell and B.N. Mamlyuk, 'Capitalism, Communism ... . and Colonialism? Revisiting 'Transitology' as the Ideology of Informal Empire’, 9:2 Global Jurist 1 (2009) pp. 2-3.

${ }^{21}$ Hobsbawm, supra note 17, pp. 95-96.
} 
engagement with other communist and 'third' world countries seemed to clearly be conducted in relation to what might be seen primarily as its own state interests and a prejudice towards a universalizable Russian identity. ${ }^{22}$

The reconstitution of the Soviet bloc in the 1990s largely maintained these juxtapositions. For example, $20^{\text {th }}$ century Russian history was an aberrational, a primitive or cancerous extended moment in the progress of humanity and the goal now was a comprehensive modern liberal program: promote national self-determination and individual human rights, free the market from state control to enable private innovation, encourage legal reforms that would allow for Russian integration into the international community and ensure democratic rule of law at home. Even the label given to this period is invocative of this characterization: 'transitology'. ${ }^{23}$ And the stakes were high as well: nationalist passions would need to be rationalized, nuclear weapon armaments would have to be contained, and more generally, Russia might be a laboratory to demonstrate the triumphalism of Western style democratic oriented capitalism - or at least that was the stance of a significant portion of the literature and political rhetoric. To the extent that these programs failed to deliver on their promises, responsibility was predominantly attributed to Russia's $20^{\text {th }}$ century totalitarian legacy, that its populations and infrastructure were not sufficiently advanced to transition successfully, or that Western policy makers had rushed the job and should have been more gradual in their timelines for reform. ${ }^{24}$

The current landscape of analysis within international law looks surprisingly familiar. First, priority is placed on preserving the territorial integrity of Ukraine linked to national selfdetermination and contrasted to an aggressive Russian state bent on political expansion. Second, and related to this first observation, the idea of an international community committed to democracy and stability is set against a Russian state that breaks the normative commitments

\footnotetext{
22 Haskell and Mamlyuk, supra note 20, pp. 2-13; see also A. Jersild, The Sino-Soviet Alliance (2014). To speak of the state is perhaps misleading to the extent that the 'state' is itself a symbol of dense institutional arrangements, which themselves have transformed according to various political exigencies and conceptual practices. For an exploration of this theme generally, see e.g., N. Poulantzas, State, Power, Socialism (1978).

${ }^{23}$ For a discussion of 'transitology' along these themes, see Haskell and Mamlyuk, supra note 20, pp. 12-15.

${ }^{24}$ Late and post-Soviet reforms are often characterized in black-and-white stories of left wing or totalitarian backsliding, but may also be viewed as a dynamic period of institutional experimentation. This is a key theme running throughout Newton's soon-to-be released scholarship.
} 
within public international law. ${ }^{25}$ Third, Russian investment and resource control is depicted as an internal threat to Britain and Europe, whereby democratic states are said to be hamstrung to energy dependence. ${ }^{26}$ Fourth, embodied in Putin, the Russian state is again characterized chiefly in militaristic terms. ${ }^{27}$ Fifth, Western media focuses almost exclusively on Russia's domestic policies that suppress the LGBT community, journalists, and social dissent. ${ }^{28}$ The overall image is a battle again between liberal and illiberal states, with Western European and Atlantic states linked to the international community, stability, and promotion of individual and national selfdetermination, and the Russian state equated with backward prejudices, totalitarian rulership and unstable foreign policy.

\section{BLIND SPOTS}

The juxtaposition of the current moment feels strikingly familiar within the lineage of

Western oriented international law and governance: Russia unable to honor international legal commitments, Russia aggressively implementing domestic measures prejudiced against identity rights and unencumbered civil expression, Russian foreign policy premised on an emergency security state model, and so forth. These claims are undoubtedly true to an extent, but it is exactly the degree that they are inaccurate or an incomplete picture that poses significant lost

\footnotetext{
25 See e.g., K. Hausler and R. McCorquodale, 'Ukraine Insta-Symposium, Ukraine and Russia: Self-Determination, Intervention and International Law', Opinio Juris, 10 March 2014, <opiniojuris.org/2014/03/10/ukraine-instasymposium-crimea-ukraine-russia-self-determination-intervention-international-law/>, visited on 30 August 2014; see also J. Sachs, 'Ukraine and the Crisis of International Law', Project Syndicate, 24 March 2014, <www.projectsyndicate.org/commentary/jeffrey-d--sachs-sees-in-russia-s-annexation-of-crimea-the-return--with-us-complicity-of-great-power-politics>, visited on 30 August 2014. For an idea that law might be the privileged, or at least most pragmatic location, for mediating a peaceful Russian foreign policy, see B. Mamlyuk, 'Uniting for 'Peace' in the Second Cold War: A Response to Larry Johnson', American Journal of International Law Unbound, 21 July 2014, $<$ www.asil.org/blogs/uniting-\%E2\%80\%9Cpeace\%E2\%80\%9D-second-cold-war-response-larry-johnson>, visited on 30 August 2014. For an alternative reading of Soviet-Western relations in historical context, see W.A. Williams, The Tragedy of American Diplomacy (2009); see also O.A. Westad, The Global Cold War (2007).

${ }^{26}$ For this potential threat in historical perspective, see P. Hogseliu, Red Gas: Russia and the Origins of European Energy Dependence (2013).

27 See K. Giles, 'Ukraine: Vladimir Putin's military action reveals a wider plan', BBC News Europe, 28 August 2014, <www.bbc.com/news/world-africa-28971901>, visited on 30 August 2014.

28 See e.g., 'Russian Federation Human Rights', Amnesty International Annual 2013 Report, <www.amnestyusa.org/ our-work/countries/europe/russian-federation>, visited on 30 August 2014.
} 
opportunity costs to scholars and policy makers involved in global governance. In this section, I lay out some blind spots with contemporary approaches to the Russian state.

The Russian state during the Soviet regime was organized from its inception in relation to the necessities of security in an emergency context. ${ }^{29}$ While a necessity in its first years, the structure of political rule became solidified over the following decades, of which Putin is most definitely a product. The importance of party politics and security-oriented governance did not, however, mean that the Russian system during the Soviet period was simply a matter of politics over law (e.g., show trials). In fact, the Russian state was constituted on a complex administrative legal structure that, especially in its first decade, represented perhaps the most extensive self-reflective experimentation with the possibilities and constraints of law itself. ${ }^{30}$ This is not to say that Russian legal scholarship is the most ideal site for this exploration. For example, in recent years, Pashukanis has become a darling within left-oriented Western based legal scholars, for his studies in the early 1920s that condemned the very form of law as intrinsically bourgeois and reproducing capitalist inequality. ${ }^{31}$ Beyond the fact that Pashukanis himself largely abandoned this thesis quickly and that it generalized the concept of law to the point of essentialism, the tendency for scholars to rely on intellectual histories to discern the actual historical sociology at play misses the relatively clear fact that legal scholarship had little weight in building or managing the administrative legal apparatus of the Soviet Union. ${ }^{32}$ Academic legal scholarship, much like today, simply did not have a strong impact on domestic or foreign policy, nor did the scholarship reflect its actual mechanisms of authority. Furthermore, as commonly noted, by the mid-20 $0^{\text {th }}$ century, the Russian state was comfortable with a positivist approach to public international law and honored its commitments within context much like its Western counterparts.

\footnotetext{
${ }^{29}$ See Gaddis, supra note 16, p. 39.

30 This is perhaps the central theme of Newton's scholarship to be released later this year on the administrative/legal structure of the Soviet system.

31 Though much of the literature on Pashukanis is relatively thin, for a notable exception see M. Head, Evgeny Pashukanis: A Critical Reappraisal (2008).

32 The relative disconnect between legal theorists and policy makers in the Soviet Union is examined in Newton's upcoming monograph, and implied in Mamlyuk, supra note 8, pp. 13, 35, 76-86, 95.
} 
There are at least three takeaways here. First, as a methodological point, there is a tremendous opportunity for scholarship that focuses on methods within historical sociology and organizational management to map out institutional logics within the Soviet Union and how law functioned between and within diverse processes. Too often scholarship seems content to analyze U.S. State Department activities, or grand political statements by Soviet policy makers, or to rely on a relatively small set of primary legal texts by famous jurists to explain the history of the Cold War. To the extent that legal scholarship mattered, it represents the knowledge production of a particular institutional setting that must be situated within diverse, and potentially very conflicting alternative institutional arrangements. ${ }^{33}$

Second, the call for measuring the Russian state according to its willingness to signal a commitment to international legal norms is a relatively empty heuristic for understanding the actual dynamics of conflict. As critical international legal scholarship has demonstrated over the past few decades, international law is complicit in what it poses as its problems, often in the very act of naming them, obscuring their potential to shift responsibility on the existing global architecture of management and production. ${ }^{34}$ In the wake of the fragmentation of the Soviet Union, the concerted push by domestic players to incorporate Russia into the conventions of the international legal order facilitated the consolidation of power and wealth by post-Soviet elite by allowing them to shift the legitimacy of rulership from communism or competing proposals for

\footnotetext{
33 The attention to institutional structures, and more specifically the interest in the dynamics of organizational change, seems to be slowly capturing the imagination of disciplinary thought collectives at the crossroads of humanities and social sciences. The specific language and principles can substantially vary depending on the given epistemic background of the community, but the trend (we might call it 'organizationalism') seems to me to exist towards thinking of complex layers of coded, impermanent structures oscillating for authority and survival in the wake of discrete and grand tendencies as the prime focus of change and meaning making. If early inroads were made by American legal realists and institutional economists in the 1920s and 1930s (e.g., Hale, Veblen), and leftoriented European philosophers and social theorists in the 60s (e.g., Althusser, Meillassoux), the more recent innovators have been generally located within departments associated with organizational management (e.g., Boltanski, Fligstein, Meyer) and economic and historical sociology (e.g., Davis, Mirowski, Tilly), and to a lesser extent international relations (e.g., Kessler, Rajkovic). International law academics have also moved in this direction, with interest in themes such as 'fragmentation', 'international organizations', and 'regionalism', but also more concretely in attempts to develop organizational heuristics, such as autopoiesis and global administrative law (e.g., Kingsbury, Rasulov, Teubner).

${ }^{34}$ For an eloquent explanation of this tendency, see D. Kennedy, 'The International Human Rights Movement: Part of the Problem?', 15 Harvard Human Rights Journal (2002) p. 101.
} 
distribution to the mantra of the international community and its rule of law. ${ }^{35}$ In other words, the impetus to assign responsibility to perceived characteristics embedded deep within the Russian state psychology is, at least partly, a rhetorical move (conscious or unconscious) to protect the necessities of particular institutional processes that have a significant role in the conceptual and 'material' constitution of global authority, and which provide a useful set of tools for allowing entrenched interests to capture future organization. ${ }^{36}$ The chemistry of the Russian (or Soviet) regime may indeed have a different configuration than Western regimes, but there is nothing fundamentally at odds in the fact of politics and status holding substantial persuasive capital over the ultimate determinacy of legal processes. The point here would be to better understand how diverse institutional contexts operate and exist in relation to each other, and to withstand the temptation to conceive of a domain of peaceful versus volatile systems without falling into the trap of shutting down the possibility of future contingency and redirection.

Third, in a related observation concerning 'liberal' complicity, the post-Soviet period 'transitology' - is remembered within development/economic scholarship as the fight between the 'shock reformers' (e.g., Sach) and the 'gradualists' (e.g., Stiglitz), which functioned against the backdrop of corrupt Soviet bureaucrats, security forces and informal economies. ${ }^{37}$ The mainstream narrative goes something like this. After the Soviet Union fell, there was an almost organic desire throughout the territories to participate in Western style lifestyles - all of which was happily embraced by the Washington Consensus within the United States, which resulted in a flood of experts arriving in the former Soviet Union to plan a fundamental neoliberal restructuring program. Problems emerged quickly as the experts are said to not have paid enough attention to the complexity of entrenched interests and institutional change. The optimism that animated the rapid, broad-brush reform packages (sometimes crafted in hours or days for an entire country) quickly turned into frustration as state resources became privatized, only to be captured by a relatively small set of former Soviet elites. It was, as Christine Freeland put it, the

\footnotetext{
35 See Mamlyuk, supra note 8, p. 195. For a more general discussion of this dynamic, see S. Pahuja, Decolonising International Law: Development, Economic Growth and the Politics of Universality (2011) pp. 128-144.

${ }^{36}$ See S. Veitch, Law and Irresponsibility: On the Legitimation of Human Suffering (2007).

${ }^{37}$ For a discussion of this literature, see Haskell and Mamlyuk, supra note 20, pp. 1527.
} 
ideological blindness of economists and policy makers, along with some old fashioned capitalist nepotism, that resulted in 'the sale of the century'. ${ }^{38}$ As 'shock therapists' lost credibility, it is said that a new camp of experts arrived on the scene, 'the gradualists', who focused on a more nuanced evaluation of how to time reforms, pay attention to cultural contexts and institutional dynamics, and so forth. The problems were not in the ideas themselves, but in their execution; it was not only a matter of getting prices right but also figuring out how to correctly coordinate institutional competencies to kick-start the economy with more participatory results. ${ }^{39}$

Among the problems with this narrative, perhaps what is immediately evident when looking to the actual interviews with the economists is that they did not see themselves in nearly the same disagreement as consensus would seem to imagine. Stiglitz's disagreement with Sachs was essentially regarding the timing of reforms; Sachs had always considered the label 'shock therapist' an exaggeration. ${ }^{40}$ When their economist counterparts in Russia were interviewed, they readily admitted to knowing that the devil was in the details of their reforms, and that regardless of any general provisions, their reforms were crafted to transfer wealth in a way that would destabilize the country. The feeling was that it would be a short term crisis, and that with the correct institutional vehicles in place, that wealth would eventually be spread. This would take time; the population would have to be patient. The United States agreed and structured aid packages to ensure the majority of funding would cycle back. Private international law norms (e.g., private property) would be enforced by a robust security/military apparatus as is common in such situations. Russian elites would be inculcated into the pleasures of Western culture, buying up soft power in exchange for slow assimilation into the existing global financial architecture. The reasoning was remarkably in line with the Scottish Enlightenment: allowing

\footnotetext{
38 Ibid., p. 29.
}

${ }^{39}$ For a discussion of how this set of concepts and practices shifted in governance talk over the course of the $20^{\text {th }}$ and early $21^{\text {st }}$ centuries, see D. Kennedy, 'The 'Rule of Law', Political Choices, and Development Common Sense', in D. Trubek \& A. Santos (eds.), The New Law and Economic Development (2006) p. 95; see also M. Blyth, Austerity: The History of a Dangerous Idea (2013); J. Bockman, Markets in the Name of Socialism: The Left-Wing Origins of Neoliberalism (2011); P. Dardot and C. Laval, The New Way of the World: On Neoliberal Society; M. Foucault, The Birth of Biopolitics: Lectures at the College de France, 1978-1979 (2010); A. Lang, World Trade Law after Neoliberalism: Reimagining the Global Economic Order (2011).

40 See Haskell and Mamlyuk, supra note 20, pp. 15-27. 
people to pursue their interests would result in the gentle civilizing hand to slowly tame political excesses. No two countries with McDonalds had ever gone to war with one another.

\section{CONCLUSion: A Great GAME OR A TOURnAment OF SHAdOWS}

In the $19^{\text {th }}$ century, the British called their conflicts with Russia 'the Great Game'. ${ }^{41}$ The wording is invocative, and which Gerry Simpson has written about eloquently in his book, 'Great Powers and Outlaw States' ${ }^{42}$ To speak of 'great' is to conjure up the 'great power politics' of the colonial experience, to speak of the big 'civilized' states, and how these great powers exercised absolute sovereignty within their own territories and foreign acquisition. For the international legal historian, this is the era when law seems the handmaiden to empire. And yet it is also a 'game'. A game requires rules, it requires laws, where even if players compete on the field, their ambition is tempered by agreed codes of conduct and shared objectives. This is also a part of our feeling about the trajectory of international law: that it acts as a gentle civilizing force upon its subjects. To speak of a great game today would be to identify the importance of clear rules and identifiable subjects - which is, to a large degree, the sentiment behind much of our professional expertise today.

The Russians had a different phrase for this conflict, 'The Tournament of Shadows'. ${ }^{43}$ Whereas games feel somewhat 'modern', the idea of a 'tournament' is reminiscent of early or pre-modern conflict, of feudal battles for status and hierarchy, to win the approval of one's master. And yet this was not a battle fought between champions, but between 'shadows'. According to the Oxford dictionary, a shadow is at once an intimation of something/someone else and a characteristic in its own right of a particular setting. ${ }^{44}$ There may still be rules, but it is not nearly so clear exactly who is playing or in what context or what those rules might be. If the

\footnotetext{
${ }^{41}$ See P. Hopkirk, The Great Game: The Struggle of Empire in Central Asia (1992).

${ }^{4}$ See G. Simpson, Great Powers and Outlaw States: Unequal Sovereigns in the International Legal Order (2004).

${ }^{43}$ See K.E. Meyer and S.B. Brysac, Tournament of Shadows: The Great Game and the Race for Empire in Central Asia (2000).

44 See Oxford Dictionary Online, <www.oxforddictionaries.com/definition/english/shadow>, visited on 30 August 2014.
} 
Russian phrase denotes a situation that is frustratingly opaque, it seems a more accurate description of the challenge before us as scholars and policy-makers.

The idea of shadows, in other words, cautions us against the temptation to slip into a particular way of thinking about the function of international law and what themes guide our analysis. For instance, the juxtaposition of liberal/illiberal feels descriptive and normatively appropriate in a conversation about Russia and the international community. ${ }^{45}$ In this story, Liberalism generally stands for democratic representation, a non-political rule of law, and an emphasis on the self-determination of individuals and communities (e.g., from artistic endeavors, to gay rights, to making money). We tend to be for liberalism; the question being either the authenticity of a liberal regime (e.g. is it actually liberal) or what are the best strategies for advancing liberalism (e.g., A.M. Slaughter's militarism, E. Hurd's intersubjective dialogical tactic). And we equally tend to be against illiberalism, which invokes a set of negative connotations ranging from $20^{\text {th }}$ century fascist regimes to 21 st century Muslim states. Perhaps no country more than Russia is subject to this rhetoric within international law and policy talk - the perennial 'other' of liberalism: whether the insatiable bear of the $19^{\text {th }}$ century, the Soviet threat during the $20^{\text {th }}$, or today as some mixture of cultural orthodoxy and security state totalitarianism, all which threats its internal populations and the peace and security of the international community. The binaries are clear - law vs. politics, tolerance vs. oppression - all of which helps us assess the situation and designate our appropriate professional responses in relation to international law.

To take seriously the idea of 'shadows' would be to second guess this set of images, of assumptions, of professional sensibilities. To speak of the state will mean to speak of a diverse configuration of institutional terrains with insulated traditions, competing interests and overlapping processes. Less constitutional dictates; more administrative procedures. And this requires an analytic framework to understand how these apparatuses in their diversity interact with one another to create determinate patterns of outcomes. Less law per se, and more

\footnotetext{
45 For a critical perspective on this tendency over the last 200 years in governance discourse, see Simpson, supra note 42 .
} 
(historical) sociology. ${ }^{46}$ And on our way we can see that labels such as capitalism, or communism, or totalitarianism mean very little - no more than words like human, or the social, or the individual. The task that this conference set out before us is indeed provocative: how can we move beyond the routinized forms that knowledge production takes in our discipline to shed new understanding on the past, and by extension, alternative frameworks for assessing what is at stake today and for whom.

46 There seems to be an increasing impetus among younger international legal scholars to pursue historically situated institutional studies of international law. See e.g., M. Fakhri, Sugar and the Making of International Trade Law (forthcoming, 2014); see also U. Ozsu, Formalizing Displacement: International Law and Population Transfers (forthcoming 2014); A. Rasulov, 'New Approaches to International Law: Imagines of a Genealogy', in J.M. Beneyto and D. Kennedy (eds.), New Approaches to International Law: The European and the American Experiences (2012) p. 151. These attempts seem to transcend individual efforts, see e.g., 'European Society of International Law Interest Group on International Legal Theory, Extra-Legal Dynamics of International Legal Theory', Call for Papers to 2014 Workshop, <www.esil-sedi.eu/node/542>, visited on 30 August 2014. 